\title{
Host-feeding patterns of Japanese mosquitoes II A host-blood identification study of daytime-resting Culex pipiens pallens in Kyoto, Japan
}

\author{
Yoshiaki KAROJI,* Osamu SASAKI,* \\ Akio KURODA* and Toshiro KARAKI* \\ Kyoto City Institute of Public Health, Nakakyo-ku, Kyoto 607, Japan
}

(Received: August 6, 1980)

\begin{abstract}
Blood meal sources of Culex pipiens pallens collected in the field during the daytime were serologically identified by the Ouchterlony method. Mosquito collections were made at two stations in two areas $4 \mathrm{~km}$ apart from each other in the suburbs of Kyoto in 1973 and 1974 by using a drop-net cage and sweeping. Blood removed from the engorged mosquito was tested against ten kinds of antisera. Eight different hosts identified were mammals to reptiles, i.e., bird, dog, cat, cow, pig, mouse, snake and human, showing that the blood meal sources of this mosquito were not restricted to a particular host, but covered a variety of animals. Feedings on birds and dogs made up the greater part of the total identified at the two stations, but the ratio of bird-feeding: dog-feeding differed between the stations suggesting that the host selectivity by this mosquito might vary depending on the availability of host animals.
\end{abstract}

\section{INTRODUCTION}

Host-blood identification studies of Culex pipiens pallens are valuable in examining the natural cycles of Japanese encephalitis (JE) virus, since several isolations of $\mathrm{JE}$ virus have been made from this mosquito in some localities of Japan (Buescher et al., 1959; Matsuyama et al., 1960; Hayashi et al., 1966).

Field studies of the host-feeding patterns of this mosquito showed two different results ; in Japan this mosquito was observed to have fed mainly on birds (Toshioka, 1960; Takahashi et al., 1971), while in China it fed chiefly on humans (Liu et al., 1959; Lu et al., 1959).

Laboratory experiments demonstrated that this mosquito could feed on a variety of hosts though there appeared to be a feeding preference among the host animals (Miyagi,

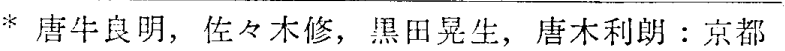
行衛生研究所（兵604 京都市中宗区壬生東高田町 $1-2)$
1972). Also in the field study, it was shown that the host range of this mosquito was comparatively wide (Karoji et al., 1980).

Host-blood identification studies of fieldcaught engorged mosquitoes have revealed some differences in host preferences among mosquitoes. It has been suggested that the host-feeding pattern of a mosquito species is not always fixed as has previously been believed, but it is changeable due to the availability of hosts (Tempelis, 1975).

Accordingly, the present study was made using a gel diffusion method in order to clarify if host availability influences on the host-feeding patterns of $C x$. pipions pallens.

\section{MATERIALS AND METHODS}

\section{Collection of mosquitoes}

Collections of blood-fed mosquitoes were carried out at two stations (A and B), $4 \mathrm{~km}$ apart from each other, in the paddy areas of Kyoto City, Japan. 
Station A was on the edge of a swamp covered with weeds and shrubs, chiefly Zizania latifolia, Polygonum Thunbergii, Salix sp., and surrounded by paddy fields. Station B was on the edge of irrigation ditches densely covered with vegetation similar to that at Station $A$ and surrounded by paddy fields.

Mosquito collections were made at Station A from May to September 1973, and at Stations A and B from April to October 1974. Samplings were performed once a week at each station. The daytime-resting mosquitoes in the vegetation at Station A were captured by using a drop-net cage $(0.5$ $\times 0.5 \mathrm{~m}$ at the base, $1.0 \mathrm{~m}$ high, the four sides covered with nylon gauze) during the two years. We could enclose the mosquitoes with the drop-net cage by placing the cage on the vegetation, and all the mosquitoes within the cage were captured by the battery-operated suction catcher. A sweep-net (42 cm in diameter) was also used at the two stations in 1974.

Blood-meal identification of engorged mosquitoes

Captured mosquitoes were anesthetized, stored in a chilled ice-box and brought to the laboratory. The blood-fed specimens were separated, counted and then dissected under a binocular microscope to remove the blood contained in the gut. The undigested blood was dissolved in $0.1 \mathrm{ml}$ of $0.01 \mathrm{M}$ phosphate-buffered saline $\mathrm{pH}$ 7.2. After frozen storage and subsequent thawing these samples were used as antigens in the Ouchterlony method (Ouchterlony, 1958).

The antisera used in the Ouchterlony method were prepared by immunizing rabbits against the sera or blood of ten kinds of animals, human, horse, cow, pig, dog, cat, mouse, chicken, snake (Elaphe quadrivirgata) and frog (Rana brevipoda). The immunization schedule was the same as that mentioned in the previous study (Karoji et al., 1980). Titers and cross-reactivity were checked by the Ouchterlony method using the sera of homologous and heterologous species as antigens. The antisera titers were $1: 2,000$ or more except for Lot 1 of the pig antiserum $(1: 500)$. Though cross-reactions occurred between the dog antiserum and cat serum, and vice versa, these could be eliminated by dilution ( $\mathrm{dog}$ antiserum 5 times and cat antiserum 7 times). Antichicken serum was used as antibird serum since it was known to react broadly with the sera of various species of birds (Tempelis and Reeves, 1962).

The procedure of the Ouchterlony method used for the host-blood identification was the same as in a previous study (Karoji et al., 1980).

Estimation of host selectivity in Cx. p. pallens

First, a comparison was made by the $\chi^{2}$ test between the feeding patterns of $C x . p$. pallens and the frequency of domestic animals present in each area. The numbers of domestic animals distributed within $0.5,1.0$ and $1.5 \mathrm{~km}$ radii from each station were counted.

Next, the degree of host selectivity was. estimated by calculating Ivlev's index of electivity (Ivlev, 1961) which was proposed as a measurement of the predator-prey relationships and is formulated as follows :

$$
E_{i}=\left(r_{i}-p_{i}\right) /\left(r_{i}+p_{i}\right),
$$

where $r_{i}$ is the percentage of a certain kind of food in the digestive organ of a predator and $p_{i}$ is that of the same kind of food present in the environment. In the present study, $r_{i}$ is the percentage of a given hostblood in the guts of the mosquitoes collected and $p_{i}$ is that of the same host present in the study area.

The value $E_{i}$ can range from +1 to -1 ; zero signifies that the mosquitoes utilize a certain kind of host without particular preference. The closer to +1 the value, the higher the degree of preference for a particular host and the closer to -1 , the higher the degree of rejection for that host.

In this procedure, the wildlife in each area was not taken into consideration as very few was present due to the heavy urbanization of the outer margins of the city. For instance, black-crowned night heron was absent from the study areas and only during the daytime could eastern carrion crows and plumed egrets be seen.

Seasonal change of $C x$. p. pallens

Seasonal changes of $C x$. $p$. pallens were observed during the two years at Station $A$. 
The population density was estimated based on the daytime-resting females captured with the drop-net cage. Because the daytimeresting mosquitoes showed the contagious distribution at their resting sites (Karoji, 1980), the magnitude of error relative to mean density was estimated by the $I_{j}$-index method (Ono and Morisita, 1969), and it ( $\varepsilon$ ) is expressed as follows :

First, $I_{\delta}$ is calculated by the formula :

$$
I_{\tilde{o}}=q \frac{\sum x_{i}\left(x_{i}-1\right)}{T(T-1)},
$$

where $q$ is the number of samples taken, $x_{i}$ is the number of individuals occurred in the $i$-th unit $(i=1,2, \cdots, q)$, and $T$ is the total number of individuals $\left(T=\sum x_{i}\right)$.

Then,

$$
\varepsilon=t \sqrt{\frac{1}{q-1}\left(I_{\delta}-1\right)+-\frac{1}{T}},
$$

where $t$ is " Student's $t$."

\section{RESULTS}

Host range of $C x$. p. pallens at Stations $A$ and $B$

Yearly totals of the identified blood at the two stations are summarized in Table 1.

In total, 728 blood meals were examined at Station A in 1973, of which 725 were identified. These blood meals were from six hosts, bird, dog, cow, cat, mouse and snake; bird- and dog-feedings made up $97 \%$ of the total identified. Only one case of heterologous double feeding (dog + bird) was observed. Three samples did not react against any of the antisera prepared.

In 1974, 539 blood meals were identified at Station A. The host range of this mosquito in 1974 was similar to that observed in the preceding year except that human blood was identified. Two cases of heterologous double feedings were observed, both of which were of dog tbird.

At Station B, 1,001 blood meals were tested, of which 984 were identified. Seven different host bloods, bird, dog, pig, cat, human, snake and cow were identified. The former two were most frequently identified as was observed at Station A. Feedings on a poikilothermic host (snake) were observed at this station, too. Four cases of heterologous double feedings were observed; one was from cat +bird and the others were all from dog+bird. Seventeen samples were unidentified.

In total at Stations $\mathrm{A}$ and $\mathrm{B}$, it was shown that $C x$. p. pallens fed on eight different hosts : bird, dog, cat, cow, pig, mouse, snake and human.

Host-feeding patterns of $C x$. p. pallens

It appeared that the host-feeding pattern of $C x . p$. pallens was related to the availability of domestic animals present in the study area, especially when the $0.5 \mathrm{~km}$ radius was considered ( $c f$. Table 2). It was concluded from the $\chi^{2}$-test that the bird-feeding: dog-feeding ratio was not significantly different from the chicken: dog ratio in the study area. For example, the $\chi^{2}$-value calculated between the bird-feeding: dog-feeding ratio and the chicken : $\operatorname{dog}$ ratio within

Table 1 Host-feeding patterns of field-caught Cx. p. pallens at Stations $\mathrm{A}$ and $\mathrm{B}$ in

\begin{tabular}{|c|c|c|c|c|c|c|c|c|c|c|c|}
\hline \multirow{2}{*}{$\begin{array}{c}\text { Station } \\
\text { (Year) }\end{array}$} & \multicolumn{9}{|c|}{ No. and the percentage (in parentheses) of positives against } & \multirow{2}{*}{$\begin{array}{l}\text { Unidenti- } \\
\text { fied }\end{array}$} & \multirow{2}{*}{ Total } \\
\hline & Human & Cow & Pig & Dog & Cat & Mouse & Bird & Snake & $\begin{array}{c}\text { Double } \\
\text { hosts }\end{array}$ & & \\
\hline $\begin{array}{c}\text { A } \\
(1973)\end{array}$ & $\begin{array}{c}0 \\
(0.0)\end{array}$ & $\begin{array}{c}8 \\
(1.1)\end{array}$ & $\begin{array}{c}0 \\
(0.0)\end{array}$ & $\begin{array}{c}168 \\
(23.2)\end{array}$ & $\begin{array}{c}8 \\
(1.1)\end{array}$ & $\begin{array}{c}3 \\
(0.4)\end{array}$ & $\begin{array}{c}536 \\
(73.9)\end{array}$ & $\begin{array}{c}1 \\
(0.1)\end{array}$ & $\begin{array}{l}1^{*} \\
(0.1)\end{array}$ & 3 & 728 \\
\hline $\begin{array}{c}\text { A } \\
(1974)\end{array}$ & $\begin{array}{c}1 \\
(0.2)\end{array}$ & $\begin{array}{c}3 \\
(0.6)\end{array}$ & $\begin{array}{c}0 \\
(0.0)\end{array}$ & $\begin{array}{c}110 \\
(20.4)\end{array}$ & $\begin{array}{c}3 \\
(0.6)\end{array}$ & $\begin{array}{c}1 \\
(0.2)\end{array}$ & $\begin{array}{c}418 \\
(77.6)\end{array}$ & $\begin{array}{c}1 \\
(0.2)\end{array}$ & $\begin{array}{l}2^{*} \\
(0.4)\end{array}$ & 0 & 539 \\
\hline $\begin{array}{c}\mathrm{B} \\
(1974)\end{array}$ & $\begin{array}{c}2 \\
(0.2)\end{array}$ & $\begin{array}{c}1 \\
(0.1)\end{array}$ & $\begin{array}{c}9 \\
(0.9)\end{array}$ & $\begin{array}{c}406 \\
(41.3)\end{array}$ & $\begin{array}{c}9 \\
(0.9)\end{array}$ & $\begin{array}{c}0 \\
(0.0)\end{array}$ & $\begin{array}{c}551 \\
(56.0)\end{array}$ & $\begin{array}{c}2 \\
(0.2)\end{array}$ & $\begin{array}{l}4^{* *} \\
(0.4)\end{array}$ & 17 & 1,001 \\
\hline
\end{tabular}
1973 and 1974

* Positive against dog and chicken antisera.

** One sample was positive against cat and chicken antisera, and the others were positive against dog and chicken antisera. 
Table 2 Indices of electivity in $C x$. $p$. pallens calculated for the radii of different distances from each station

\begin{tabular}{|c|c|c|c|c|c|}
\hline \multirow{2}{*}{$\begin{array}{c}\text { Distance } \\
\text { (Radius in } \mathrm{km} \text { ) }\end{array}$} & \multicolumn{5}{|c|}{ Ivlev's index of electivity } \\
\hline & Chicken & Dog & Cat & Cow & Pig \\
\hline \multicolumn{6}{|c|}{ Station A in 1973} \\
\hline 0.5 & $0.08(60)$ & $0.13(17)$ & $-0.87(15)$ & - & - \\
\hline 1.0 & $0.04(157)$ & $0.18(37)$ & $-0.85(31)$ & - & - \\
\hline 1.5 & $0.05(264)$ & $0.23(57)$ & $-0.78(36)$ & $-0.77(34)$ & - \\
\hline \multicolumn{6}{|c|}{ Station A in 1974} \\
\hline 0.5 & $0.09(60)$ & $0.06(17)$ & $-0.93(15)$ & - & - \\
\hline 1.0 & $0.06(157)$ & $0.12(37)$ & $-0.92(31)$ & - & - \\
\hline 1.5 & $0.05(304)$ & $0.22(57)$ & $-0.87(36)$ & $-0.87(34)$ & - \\
\hline \multicolumn{6}{|c|}{ Station B in 1974} \\
\hline 0.5 & $-0.01(52)$ & $0.08(32)$ & $-0.70(5)$ & - & - \\
\hline 1.0 & $-0.08(8,000)$ & $0.95(130)$ & $0.71(20)$ & - & $-0.95(4,000)$ \\
\hline 1.5 & $-0.07(8,000)$ & $0.90(280)$ & $0.45(45)$ & $-0.60(50)$ & $-0.95(4,000)$ \\
\hline
\end{tabular}

Actual number of individuals are shown in parentheses.

- : absent.

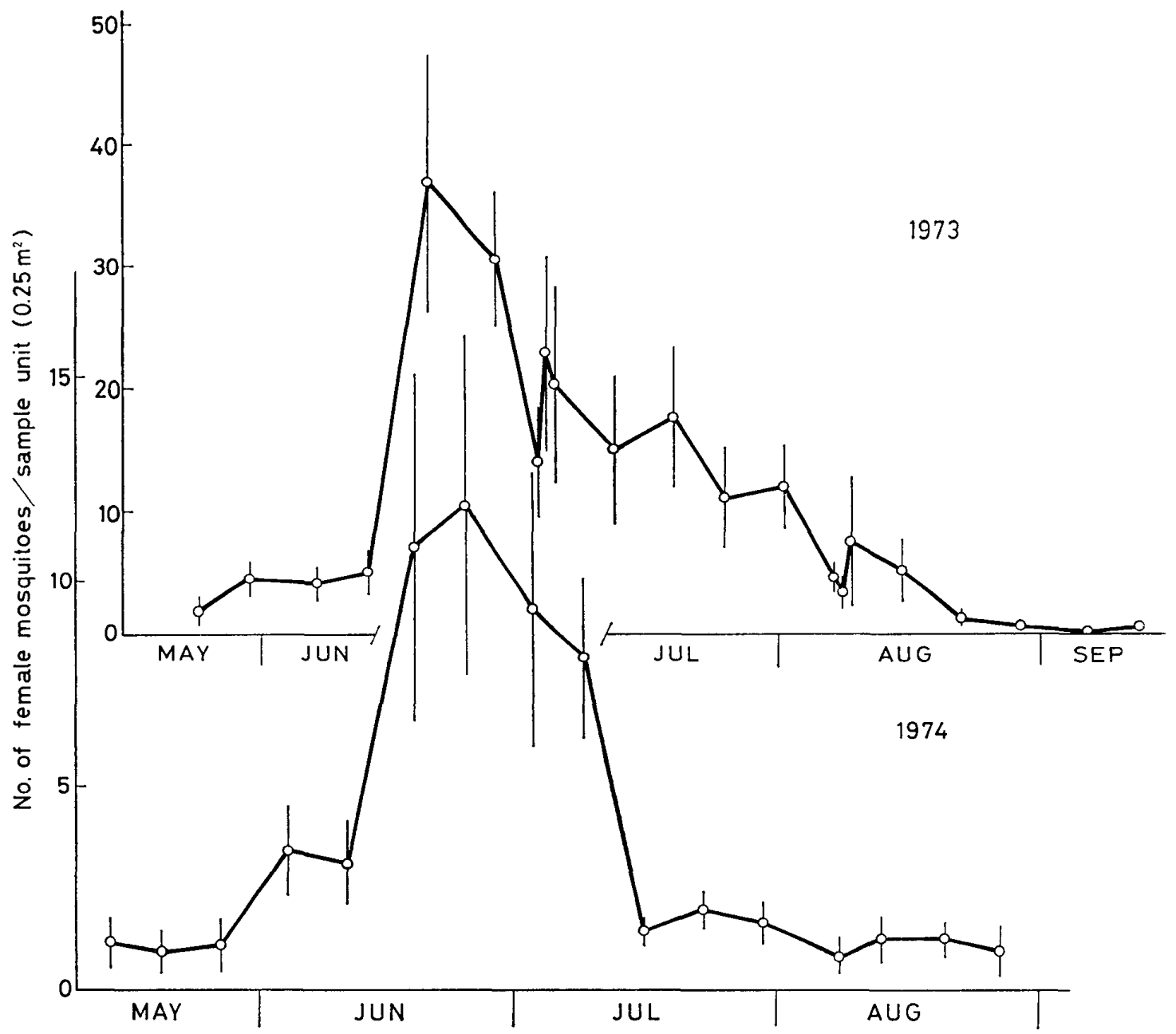

Fig. 1 The seasonal changes in the population density of the daytime-resting females of Cx. p. pallens at Station A in 1973 and 1974

Mean density (open circle) and the magnitude of error relative to mean density calculated by the $I \delta$-index method (vertical thin line) are shown. 
$0.5 \mathrm{~km}$ radius from Station A in 1973 was $0.122(p>0.70)$, and the comparable $\chi^{2}$-values calculated at Station A and at Station B in 1974 were $0.063(p>0.80)$ and $0.594(p>0.30)$, respectively.

It was observed that the feeding pattern of this mosquito at Station A differed from that at Station B in $1974 \quad\left(\chi^{2}=69.959, p<\right.$ 0.001 ).

Secondly, Ivlev's indices of electivity were calculated and tabulated for $0.5,1.0$ and $1.5 \mathrm{~km}$ ranges from each station, respectively (Table 2).

The indices were comparatively close to zero in the cases of chicken and dog, except for those of dog within 1.0 and $1.5 \mathrm{~km}$ radii from Station B. In contrast, indices were generally close to -1 in the cases of cat, cow and pig.

Seasonal changes in Cx. p. pallens population

Seasonal changes in the female $C x$. p. pallens population at Station $\mathrm{A}$ are shown for the two years (Fig. 1). It is apparent that a similar fluctuation pattern prevailed both in 1973 and 1974 though the population density was higher in 1973 than in 1974. Active populations of $C x$. $p$. pallens were already present as early as May and attained the highest density in late-June.

\section{DISCUSSION}

In the past, $C x$. $p$. pallens was believed to feed exclusively on birds in Japan (Sasa, 1955). When observed in the field, however, it was clear that this mosquito fed on several kinds of animals as well as birds (Liu et al., 1959 ; Takahashi et al., 1971; Karoji et al., 1980). Toshioka (1960) stated that this mosquito preferred chickens but it also fed on other animals when chickens were not readily available.

The present study showed that the host range of this mosquito in the field was not restricted to birds but that it included eight different hosts ranging from mammals to reptiles. It was also demonstrated that the host-feeding patterns differed from those of preceding works. Our result might be interpreted as indicating that this mosquito fed on chickens and dogs, not because it had a particular preference for either of these animals, but because they were readily available in the study areas. It was shown that the feeding patterns were different between the two areas and paralleled with the ratio of chickens to dogs in the areas. Therefore, the result could be interpreted as showing that $C x$. p. pallens has flexible preferences and these are determined by the available hosts.

The problem how large a study area should be carried out for collecting unbiased samples of engorged mosquitoes for the hostblood identification study has already been discussed. The flight range of mosquitoes after taking blood-meals generally has been thought to be short (Nakao, 1959; Shemanchuk et al., 1963), but others observed that it was surprisingly wide (Edman and Bidlingmayer, 1969). Cx. p. pallens appears to be able to move over $1 \mathrm{~km}$ after engorgement, as exemplified in the present study, since Station A where the cow-feedings were detected was about $1.3 \mathrm{~km}$ away from the hosts and similarly Station B about $1.2 \mathrm{~km}$ away. A more accurate survey should be made on the flight dispersal of mosquitoes after bloodfeeding.

It is noteworthy that $C x$. p. pallens is already active, despite low density, in May in Japan, and attains a high level of population density in late-June. The population trend in the fall was not followed in the present study, but $C x$. p. pallens was observed to feed on its hosts and rest in the ripened rice fields even in mid-October (Karoji, unpublished data). Thus, the active period of this mosquito lasts from spring to fall as has been observed by other workers (Sasa et al., 1951).

It could be considered that $C x$. p. pallens does not play an important role in the pigmosquito cycle of JE virus during the epidemic season since laboratory experiments have revealed that the susceptibility of this mosquito to JE virus was lower than that of Cx. tritaeniorhynchus (Hammon et al., 1949 ; Doi et al., 1977 ; Karoji et al., 1977), and only occasionally has JE virus been isolated from field-caught $C x$. p. pallens (Buescher et al., 1959; Matsuyama et al., 1960; Hayashi et al., 1966).

Despite the facts mentioned above, the 
role of $C x . p$. pallens in the natural cycles of $\mathrm{JE}$ virus should not be ignored because the unknown pathways of this virus may involve this species which has a wide range of hosts in the field.

\section{ACKNOWLEDGEMENTS}

We wish to express our thanks to Prof. N. Ishida, Tohoku University, Prof. Y. Ozaki, Shiga University of Medical Science, and Prof. T. Ishii, University of Tokushima, for their sincere advice and criticism during the course of our study. Our gratitude is also dedicated to Prof. R. Kano, Tokyo Medical and Dental University, for kindly offering us the references.

\section{REFERENCES}

Buescher, E. L., W. F. Scherer, M. Z. Rosenberg, I. Gresser, J. L. Hardy and H. R. Bullock (1959): Ecologic studies of Japanese encephalitis virus in Japan. II. Mosquito infection. Am. J. Trop. Med. Hyg., 8(6): 651664.

Doi, R., A. Shirasaka, M. Sasa and A. Oya (1977): Studies on the susceptibility of three species of mosquitoes to Japanese encephalitis virus. J. Med. Entomol., 13 : 591-594.

Edman, J. D. and W. L. Bidlingmayer (1969): Flight capacity of blood-engorged mosquitoes. Mosq., News, 29 : 386-392.

Hammon, W. McD., D. M. Rees, J. Casals and G. Meiklejohn (1949): Experimental transmission of Japanese B encephalitis virus by Culex tritaeniorhynchus and Culex pipiens var. pallens, suspected natural vectors. Am. J. Hyg., $50: 46-50$.

Hayashi, K., K. Mifune, A. Shichijo, H. Kawasoe, S. Matsuo, K. Futatsuki, N. Omori, Y. Wada, S. Ito, S. Kawai, J. Nishigaki, Y. Abe, K. Makiya and Y. Kamizono (1966) : Ecological studies on Japanese encephalitis virus. Isolation of Japanese encephalitis virus from mosquitoes collected in Nagasaki and Kagoshima Districts, Japan, in 1965. Endem. Dis. Bull. Nagasaki Univ., 8(2): 61-73.

Ivlev, B. C. (1961) : Experimental Ecology of the Feeding of Fishes, Scott, D. (Transl.), 302 pp., Yale Univ. Press, New Haven.

Karoji, Y., A. Kuroda, O. Sasaki, T. Karaki, K. Takenokuma and O. Maeda (1977): Susceptibility of four species of mosquitoes to Japanese encephalitis virus as examined by larval infection. Virus, 27 (1): 34-39. (in Japanese with English Summary)

Karoji, Y. (1980): The spatial distribution pat- tern of the daytime-resting populations of adult mosquitoes in the paddy area. Jap. J. Sanit. Zool., 31(1): 1-6.

Karoji, Y., R. Shiraji and N. Ishida (1980) : Hostfeeding patterns of Japanese mosquitoes $I$. Blood meal sources of some mosquitoes in a paddy area. Jap. J. Sanit. Zool., 31(4): 283288.

Liu, C., S. Chang, Y. Cheng and Y. Wang (1959) : Studies on vectors of Japanese encephalitis virus in Peking. II. Studies on the blood feeding habits of common species of mosquitoes in Peking. Acta Entomol.Sin., 9(1): 5156.

Lu, S., T. Ma and C. Lee (1959): The blood preference of some culicine mosquitoes in rural areas of Nanking. Acta Entomol.Sin., 9(2): 178-182.

Matsuyama, T., A. Oya, T. Ogata, I. Kobayashi, T. Nakamura, M. Takahashi and M. Kitaoka (1960): Isolation of arbor viruses from mosquitoes collected at live-stock pens in Gumma Prefecture in 1959. Jap. J. Med. Sci. Biol., 13 : 191-198.

Miyagi, I. (1972) : Feeding habits of some Japanese mosquitoes on cold-blooded animals in laboratory. Trop. Med., 14: 203-217. (in Japanese with English Summary)

Nakao, S. (1959): Ecological studies on the community of adult mosquitoes resting in the grass in the daytime. III. Resting habits of some mosquitoes. Jap. J. Sanit. Zool., 10 : 8-15. (in Japanese with English Summary)

Ono, Y. and M. Morisita (1969): Estimating method of population density of citrus pest insects, mites, and diseases in citrus groves or trees. In Studies on Improvement of Collective Control of Citrus Tree Pests, 245 pp., Japan Plant Protection Association, Tokyo.

Ouchterlony, Ö. (1958) : Diffusion-in-gel methods for immunolgical analysis. Prog. Allergy, 5: $1-78$.

Sasa, M., R. Kano, S. Hayashi, K. Kimura, A. Miura, K. Oyama, K. Sato, H. Hosoya and K. Hasegawa (1951): Two year's observation on the seasonal activities and zoophilism of mosquitoes in Tokyo by animal trap method. Jap. J. Exp. Med., 20 : 509-517.

Sasa, M. (1955): Mosquitoes in Japan, 91 pp., DDT-Kyokai, Tokyo. (in Japanese)

Shemanchuk, J. A., A. E. Downe and L. Burgess (1963): Hosts of mosquitoes (Diptera: Culicidae) from the irrigated areas of Alberta. Mosq. News, 29 : 386-392.

Takahashi, M., S. Yabe and Y. Shimizu (1971): Observations on the feeding habits of some mosquitoes in Gumma Prefecture, Japan. Jap. 
J. Med. Sci. Biol., 24 : 163-169.

Tempelis, C. H. and W. C. Reeves (1962): The production of a specific antiserum to bird serum. Am. J. Trop. Med. Hyg., 11: 294297.

Tempelis, C. H. (1975): Host-feeding patterns of mosquitoes, with a review of advances in analysis of blood meals by serology. J. Med. Entomol., 11 : 635-653.

Toshioka, S. (1960): Serological investigation on the feeding habit, host preference, and blood meal of mosquitoes in Tokyo District. Ochanomizu Med. J., 8: 103-113. (in Japanese with English Summary)

\author{
摘 要 \\ 日本産蚊類の宿主吸血パターン II \\ 京都市の水田地域に拧けるアカイエカの \\ 吸血宿主
}

日中，野外で休止している吸血アカイエカを採集し， その吸血源をゲル内沈降反忘の 1 種 Ouchterlony 法に より判定した. 吸血蚊の採集は，1973年と1974年に京都 市南部の水田地域の, 東西にほほ $4 \mathrm{~km}$ 離れた 2 力所の ステーションで, ドロップネット・ケージとスイーピン グにより行った。吸血蚊の吸血血液を，哺乳類から把虫 類にわたる 10 種の動物の抗血清を用いてテストした結 果, トリ，イヌ、ネコ, ウシ, ブタ,ネズミ, ヘビ，七 トの 8 種の吸血源が判定され，この蚊の吸血は特定の宿 主に限定されているのではなく, 広い宿主幅を持ってい ることが示された。いずれのステーションにおいても， トリ吸血とイヌ吸血が吸血例の大部分を占めていたが, 両者の比率はステーション間で異なっており，この蚊の 宿主選択が，その地域に分布している宿主動物の比率に 依存している可能性を示していた。 